\title{
The relationship between technology acceptance and frequency of mobile commerce use amongst Generation $Y$ consumers
}

\begin{abstract}
Authors:
Nobukhosi Dlodlo

Chengedzai Mafini ${ }^{2}$

Affiliations:

${ }^{1}$ Department of Marketing and Sport Management, Vaal University of Technology,

South Africa

${ }^{2}$ Department of Logistics, Vaal University of

Technology, South Africa

\section{Correspondence to:}

Nobukhosi Dlodlo

Email:

nobukhosid@vut.ac.za

Postal address:

Private Bag X021,

Vanderbijlpark 1900,

South Africa

Dates:

Received: 12 Feb. 2013

Accepted: 26 Mar. 2013

Published: 10 May 2013

How to cite this article: Dlodlo, N. \& Mafini, C., 2013

'The relationship between technology acceptance and frequency of mobile commerce use amongst Generation Y consumers', Acta Commercii 13(1), Art. \#176, 8 pages. http://dx.doi. org/10.4102/ac.v13i1.176
\end{abstract}

\section{Copyright:}

(C) 2013. The Authors.

Licensee: AOSIS OpenJournals. This work

is licensed under the Creative Commons Attribution License.
Read online:

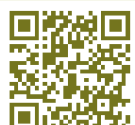

Orientation: The South African mobile commerce industry has realised an exponential growth in the past few years, yet the Generation $Y$ market segment has failed to keep pace with this growth.

Research purpose: To examine the nature of the relationships that exist between technology acceptance and frequency of mobile commerce usage amongst Generation Y consumers.

Motivation for the study: The Generation Y cohort has emerged as an important age-group due to its economic contribution to the economy. It is therefore essential that their attitudes and behaviour continue to receive empirical introspection, particularly since mobile commerce has gathered momentum as an important and arguably, the most popular medium for commercial transactions. In a global space that is technology based, it becomes imperative to investigate the interplay between mobile commerce acceptance dimensions and frequency of use amongst Generation Ys.

Research design, approach and method: A survey was conducted with the aid of a structured self-administered questionnaire with a view to collecting primary data from a sample consisting of 204 Generation Y consumers.

Main findings: There were positive correlations between frequency of use and five mobile commerce acceptance dimensions. Cronbach Alpha values ranged between 0.714 and 0.898 , thereby indicating high internal consistency amongst the subscales as well as within the entire survey instrument. Correlation coefficients ranged between 0.164 and 0.677 at both the $p<0.01$ and $p<0.05$ significance levels (2-tailed test), indicating very high levels of association amongst the subscales. Predictive validity of the five subscales and the variable frequency of use resulted in positive and statistically-significant results that were established at an adjusted $R^{2}$ value of 0.674 .

Practical/managerial implications: Marketers and business practitioners are presented with practical insights into dimensions that enhance frequency of use of mobile commerce technology amongst Generation Y consumers. Furthermore, an increased usage of mobile commerce technologies is projected to have a stimulus effect on profitability, sustainability and loyalty of this important market segment.

Contribution/value-add: Frequency of use is a good predictor of Generation Y consumers acceptance of mobile commerce as justified by the positive and statistically significant results of this study.

\section{Introduction}

The use of wireless and mobile technologies for conducting commercial activities continues to rise phenomenally in most continents of the world (Ngai \& Gunasekaran 2007:3). From a regional perspective, Africa has not been excluded from this trajectory. Reports from the International Telecommunications Union (ITU 2011) indicate that South Africa is ranked the third mostdeveloped African nation, after Mauritius and Seychelles, respectively, in terms of mobile Internet usage and Information communications technology (ICT). Within the same vein, mobile commerce services have also relished tremendous success in terms of individual consumers' acceptance in markets such as Japan (AlHinai, Kurnia \& Johnston 2007:200), Germany and the United Kingdom (Awa, Nwibere \& Inyang 2010:2). However, it has not flourished as astoundingly in Botswana or Nigeria (Uzoka, Shemi \& Seleka 2007:12), or amongst other third-world developing nations (Mutula 2002:506). This path continues to exist, despite ample evidence that mobile technologies enhance the long-term growth rates of national economies and that their impact is twice as big in developing nations as in developed ones (James \& Versteeg 2007:120). Moreover, mobile commerce (henceforth referred to as m-commerce) penetration leads to increased gross domestic product (GDP) growth, particularly amongst low-income developing countries (Donner 2008:146). 
Therefore, an apparent need exists for the proper stimulation and re-evaluation of $\mathrm{m}$-commerce and its relatable issues in most of the lesser-developed countries (Mutula \& Van Brakel 2006:412).

An analysis of m-commerce dynamics within the context of South Africa offers interesting insights. Modimogale and Kroeze (2011:10) found that over the years, awareness and usage of $3 \mathrm{G}$ and WAP-driven mobile technology in South Africa has undergone an explosive amplification. Koutras (2006:98) attributes this ambit to the September 2005 decision to liberalise the South African telecommunications sector. This decision allowed mobile phone operators to obtain fixed telecommunication links from suppliers other than Telkom. This consequently triggered accelerated competition amongst participants in this sector in addition to actuating growth and significantly lowering telecommunication costs (Hodge 2005:495).

This development has steered an increased reliance on mobile technologies as a platform for commercial transactions amongst South African consumers. Some related applications that have gained widespread acceptance amongst consumers include, inter alia, mobile auctions, video-on-demand, mobile payments (the ability to pay small amounts using mobile phones), mobile-banking (managing bank accounts and balances; making transfers on the move), flight and hotel reservations, m-entertainment (games, content, animation, wallpapers, music, applications) (Mthethwa 2004:5). It can therefore be argued that the benefits that can be derived from the use of mobile technologies amongst individuals, groups and organisational consumers are manifold.

\section{The background of mobile-commerce}

There is no single universally-accepted definition for $\mathrm{m}$-commerce. However, a common conceptualisation is that it is any direct or indirect transaction that has potential monetary value and is conducted through wireless telecommunication networks (AlHinai et al. 2007:201-202; Wu \& Wang 2005:720). Phillips (2003:11) defines m-commerce as being the buying and selling of goods and services using wireless handheld devices such as mobile phones and personal digital assistants (PDAs). Ulhøi and Jørgensen (2008:2) further define m-commerce as a contraption that allows Internet transactions to be conducted with a mobile commercially-enabled device without any plug-ins. Ngai and Gunasekaran (2007:4) established that m-commerce may be perceived as a novel, expanding technological application that is largely characterised by high levels of mobility, ubiquity and broad reach. The present study encompasses an all-inclusive perspective of $\mathrm{m}$-commerce that is a synthesis of the aforementioned parameters; particularly with reference to South Africa's youthful media generation.

\section{The Generation $Y$ age cohort and mobile- commerce acceptance in South Africa}

Age can be a useful instrument when defining developing trends and established patterns amongst individuals and consumer groups. The age-based subculture may be construed as being a group of people who have experienced a common social, political, historical and economic environment (Koutras 2006:124). In South Africa, mobile phones have enjoyed tremendous growth over the past decade, especially amongst the youthful 'media-conscious' generation. They have acculturated into a media-saturated and materialistic environment with convergent media that is wired to provide instantaneous global news and a platform for social networking (Cant \& Machado 2005:45). The terms 'Generation $\mathrm{Y}^{\prime}$, 'millennium generation' and 'echo boomers' have been used in previous studies when referring to a constellation of individuals who were born either between the years of 1977 and 1994 or between 1982 and 2000 (Schiffman \& Kanuk 2010:410). In the South African context, these individuals were inadvertently the first generation to enjoy the fruits of democracy in South Africa, post-1994.

In adoption research, the technology acceptance model (TAM) focuses on the attitudinal explanations of intention to use a specific technology or service (Davis 1989:320; Davis, Bagozzi \& Warshaw 1989:1001). It includes five concepts, namely, perceived user friendliness, perceived usefulness, attitude towards use, intention to use and actual use (Awa et al. 2010:4). TAM presents two particular attitudinal determinants, namely, perceived ease of use (PEOU) and perceived usefulness (PU) for a specific application system, and explains relationships amongst attitudes, intention to use and actual application usage (Venkatesh 2000:345). PEOU is defined as being 'the degree to which a person believes that using a particular system would be free of effort' (Davis 1989:320). Users are more likely to increase frequency of usage if the application is perceived to be easier to use than another (Cheung et al. 2003:198). The findings of a study conducted by Clarke (2000:14) reveal that PEOU is one of the five underlying dimensions that influence continuation in the usage of wireless handheld devices amongst consumers. This signifies that ease of use is an important determinant of consumers' acceptance and continuous usage of m-commerce technologies.

PU may be defined as being 'the degree to which a person believes that using a particular system would enhance his or her job performance' (Pearson \& Grandon 2004:199). Within the same light, consumers are willing to spend more hours on m-commerce technologies if so doing facilitates the faster and easier completion of transactions. Technology users expect a positive use-performance relationship when they perceive a high level of usefulness of a specific mobile device application.

Ajzen (1985:33) promulgated the theory of reasoned action (TRA) which emphasises succinctly the inclusion of subjective norms (SN), notably represented as an important addition when compared to the TAM. In TRA, the subjective norm variable is composed of the user's perception of how others think that they should behave, as well as their motivation to comply with the expectations of these referents (Fishbein and Ajzen 1975). Belief systems influence attitudes, which in turn shape intentions and intentions then generate either positive 
or negative behavioural actions through actual Internet commerce usage patterns (Awa et al. 2010:7; Mathieson 1991:178). The observable m-commerce adoption behaviour of individuals and groups is therefore a culmination of a series of psychological processes that occur due to the influence of these individuals and groups.

Bruner and Kumar (2005:557 applied the TAM to consumer adoption of handheld Internet devices and found that, as proposed by Davis (1989:320), a user's PEOU is a key determinant of its PU, which in turn influences behavioural intention and actual use. However, Venkatesh, Speier and Morris (2002) further incorporated an additional component of 'fun' or 'perceived enjoyment' to their model and their results indicated that both perceived usefulness and, especially, fun associated with the mobile device contribute to consumer adoption and usage of Internet-related technologies.

\section{Problem statement}

The adoption of m-commerce is dependent on consumer acceptance of new and well-designed technologies. In recent times, studies on technology adoption have sought to gain an understanding of the mobile consumer by examining a variety of trends that exist amongst different countries with regard to customers' usage of m-commerce technologies. This has provided a clear indication of the course to be deployed by researchers and service providers in theoretical studies as well as in marketing strategy formulation. However, in most of these studies, dependent variables have been 'attitude' (Mathieson 1991:178), 'acceptance' (Shi2004:355), 'preference', 'satisfaction' and 'intention' (Venkatesh 2000:345) as well as 'actual use' (Koutras 2006:120-128). In their meta-analysis of online consumer behaviour, Cheung et al. (2003:216) stated that 'compared to intention and adoption, continuance is an under-researched area'. In particular, Flavián, Guinalíu and Gurrea (2006:8) stressed that frequency of use (an indicator of continuance) is an important construct to consider for online studies. This being the case, the present study seeks to address this gap within the South African m-commerce environment.

Several additional dimensions also present a further impetus toward conducting the present study. Firstly, mobile wireless technology has been studied extensively in developed countries, but there is an apparent deficiency of similar studies that are focused on developing countries (Abdelkarim \& Nasereddin 2010:53). Secondly, most studies that were conducted within the milieu of South Africa were only directed at individuals and groups that previously did not have access to telecommunications, especially in the period prior to 1994 (Donner 2008:142). Finally, there also exists insufficient research evidence that provides a better understanding of customers' perceptions of m-commerce acceptance (Santos 2003:233). This demonstrates that an inconsistency exists in mobile commerce research, particularly within the backdrop of frequency of usage of mobile technologies by Generation Y consumers (Fassnacht \& Koese 2006:19; Koutras 2006:110). Therefore, the present study examines the interconnection between m-commerce technology acceptance and frequency of use amongst Generation Y consumers within a South African context.

\section{Research method and design Instrumentation and data collection procedures}

In the present study, a quantitative approach was used to collect the data. A questionnaire was constructed and administered to a conveniently-recruited sample of 250 individuals born between 1977 and 1994 (Generation Y) who owned a mobile device. This sample size is consistent with previous studies conducted by Kim, Ma and Park (2009:222), Gao, Sultan and Rohm (2010:578) and Abdelkarim and Nasereddin (2010:54). These respondents were selected from students at a large university of technology located in the Gauteng Province, South Africa. The sample was composed of university students only because mobile device usage is very high amongst this group (Burns 2005:12) and they also use mobile phones in a wide spectrum of applications such as text messaging, phone calls and emailing, amongst others (Thottam 2005:45). Furthermore, the involvement of students does not necessarily lead to significantly different results in studying frequency of usage of most IT innovations (Agarwal \& Karahanna 2000:690).

In the survey, the research instrument (questionnaire) was divided into five sections, with Section A eliciting general information pertaining to the respondents' profile. The questions in Sections B, C and D were anchored on a 5-point Likert scale which ranged from 1 (Strongly disagree) to 5 (Strongly agree). These sections measured the constructs of perceived usefulness (PU), perceived ease of use (PEOU) and subjective norms (SN), as well as perceived enjoyment (PE). The Likert scale was used as it is relatively easy to construct and makes data easy to collect and analyse, thereby making it suitable for surveys (Kothari 2008:34).

Operational measures and scale items were adapted from validated and pre-existing instruments that had been developed previously in order to test various aspects of technology acceptance. These instruments were modified slightly in order to make them more applicable within the context of m-commerce in South Africa. The validated scales of Mathieson (1991) and Mohd Suki and Mohd Suki (2011) were adapted to configure the PU subscale. Variables that were utilised included (1) 'enhances my work productivity', (2) 'saves effort' and (3) 'saves time' in performing tasks. The PEOU subscale was adapted from the technology acceptance scales of Davis (1989) and Venkatesh (2000). Examples of variables that were utilised for PEOU included: when conducting commercial transactions, my mobile device is (1) 'easy to use', (2) 'easy to understand' and (3) 'requires limited mental effort'. The SN subscale was adapted further from the pre-existing Internet technology acceptance scales of Hsu and $\mathrm{Lu}$ (2004) as well as Shi (2004), with the respondents responding to variables such as (1) 'people important to me influence my usage of m-commerce', (2) 'people who are important to me think that I should use m-commerce' 
and the variable (3) 'I do not rely on the recommendations of people', which was reverse-coded. PE was measured by items adapted from the scales of Venkatesh (2000) and later revised by Venkatesh et al. (2002) as well as Shambare, Rugimbana and Zhowa (2012). Variables that were included comprised, inter alia, transacting on my mobile-device is (1) 'entertaining', (2) 'enjoyable', (3) 'fun', (4) 'exciting' and (5) 'appealing'. However, in Section E, a 5-point semantic differential scale with graduations ranging from 1 (Never) to 5 (Frequently) was also used to measure the type of mobile commerce application (MCA) subscale in tandem with the respondents' frequency of usage of each application. Items included (1) 'entertainment', (2) 'purchasing tickets', (3) 'mobile downloads', (4) 'mobile banking transactions', (5) 'account payments', (6) 'information services' and (7) 'Internet services'. This section was made up of seven items that were adapted from the reliable pre-existing mobile phone usage instrument that was developed by Koutras (2006).

\section{Validity of the study}

Convergent validity was assessed through the computation of correlations among the five m-commerce acceptance subscales and frequency of use (Table 4). Predictive validity of the scale was assessed through regression analysis, thereby depicting that perceived enjoyment, perceived usefulness, perceived ease of use, m-commerce application and subjective norms have a positive causal relationship with frequency of use. In order to ascertain content validity, the questionnaire was pretested with a convenient sample of 20 students. The pretesting exercise also enabled the researchers to ascertain that the questionnaire used in the main survey would capture validly the information sought by the researchers (Sudman \& Blair 1998:95). In addition, the questionnaire was also reviewed by two academics who are experts in the fields of electronic commerce and information technology. This enabled the researchers to identify and eliminate problems with regard to the sequencing and wording of various questions. Feedback from the convenient sample and the experts enabled the researchers to make minor changes to the final questionnaire.

\section{Ethical considerations}

Ethical considerations such as the participants' right to anonymity, confidentiality, privacy or non-participation, informed consent and protection from discomfort, harm and victimisation, amongst others, were adhered to during the data collection process. An accompanying letter containing the names of the authors and an explanatory statement highlighting the purpose of the study were attached to the questionnaire.

\section{Results \\ Data analysis}

In the present study, data analysis was conducted using the Statistical Package for the Social Sciences, Version 20.0 (SPSS 2012).

\section{Profile of respondents}

Table 1 highlights the profile of the respondents for the current study.

The table indicates that approximately 63\% $(n=128)$ of the respondents were female and $37 \%(n=76)$ were males. Remarkably so, female students were also the majority respondents in a number of similar studies (Du Plessis, Berndt \& Petzer 2009:6; Koutras 2006; Van Rooi 2011:44) which were conducted amongst South African Generation Y university students. This trend could be indicative of either a higher willingness by female Generation Ys at universities to participate in research studies or the fact that there are generally more female Generation $Y$ students than males at South African Universities. The latter supposition concurs with Osava's (2010:1) assertion that females comprise the overall majority amongst university students in South Africa. In terms of age, the majority of the respondents $(72 \% ; n=147)$ were aged between 21 and 25 years. With regard to race, at least $94 \%(n=194)$ of the respondents were Blacks. This trend is in line with the report by the International Education Association of South Africa (2010), which reveals that there are more Black students than other races at South African universities. Furthermore, approximately $48 \%(n=98)$ of the respondents were postgraduate students and the remainder $(52 \% ; n=106)$ were undergraduates (first years to third years). This distribution demonstrates that all categories of students were represented sufficiently in the sample, which eliminated sampling bias.

Most of the respondents owned either a cell phone (66\%; $n=135)$ or a smart phone $(31 \% ; n=64)$. This distribution demonstrates a limited inclination toward more sophisticated mobile devices such as iPads and PDAs amongst Black Generation Ys. Respondents who had owned their mobile

TABLE 1: Demographic composition of respondents.

\begin{tabular}{|c|c|c|c|c|}
\hline Variable & Categories & $N$ & $n$ & $\%$ \\
\hline Gender & $\begin{array}{l}\text { Males } \\
\text { Females }\end{array}$ & $\begin{array}{l}204 \\
204\end{array}$ & $\begin{array}{c}76 \\
128\end{array}$ & $\begin{array}{l}37 \\
63\end{array}$ \\
\hline Age & $\begin{array}{l}\text { Between } 16-20 \text { years } \\
\text { Between } 21-25 \text { years } \\
\text { Between } 26-30 \text { years } \\
\text { More than } 30 \text { years }\end{array}$ & $\begin{array}{l}204 \\
204 \\
204 \\
204\end{array}$ & $\begin{array}{c}38 \\
147 \\
10 \\
9\end{array}$ & $\begin{array}{c}19 \\
72 \\
5 \\
4\end{array}$ \\
\hline Race & $\begin{array}{l}\text { Black } \\
\text { White } \\
\text { Indian } \\
\text { Coloured }\end{array}$ & $\begin{array}{l}204 \\
204 \\
204 \\
204\end{array}$ & $\begin{array}{c}194 \\
1 \\
5 \\
4\end{array}$ & $\begin{array}{c}94 \\
1 \\
3 \\
2\end{array}$ \\
\hline Year at the University & $\begin{array}{l}\text { First year } \\
\text { Second Year } \\
\text { Third Year } \\
\text { Postgraduate }\end{array}$ & $\begin{array}{l}204 \\
204 \\
204 \\
204\end{array}$ & $\begin{array}{l}29 \\
30 \\
47 \\
98\end{array}$ & $\begin{array}{l}14 \\
15 \\
23 \\
48\end{array}$ \\
\hline $\begin{array}{l}\text { Type of mobile device } \\
\text { owned }\end{array}$ & $\begin{array}{l}\text { Cell-phone } \\
\text { Smartphone } \\
\text { Tablet PC (e.g. IPAD) } \\
\text { Personal Digital Assistants }\end{array}$ & $\begin{array}{l}204 \\
204 \\
204 \\
204\end{array}$ & $\begin{array}{c}135 \\
64 \\
2 \\
3\end{array}$ & $\begin{array}{c}66 \\
31 \\
1 \\
2\end{array}$ \\
\hline $\begin{array}{l}\text { Length of time owning the } \\
\text { mobile device }\end{array}$ & $\begin{array}{l}\text { Less than one year } \\
\text { Between } 2-4 \text { years } \\
\text { Over } 4 \text { years }\end{array}$ & $\begin{array}{l}204 \\
204 \\
204\end{array}$ & $\begin{array}{l}71 \\
77 \\
56\end{array}$ & $\begin{array}{l}35 \\
38 \\
27\end{array}$ \\
\hline Network Provider & $\begin{array}{l}\text { MTN } \\
\text { Vodacom } \\
\text { Cell-C } \\
\text { Virgin Mobile } \\
\text { 8ta }\end{array}$ & $\begin{array}{l}204 \\
204 \\
204 \\
204 \\
204\end{array}$ & $\begin{array}{c}104 \\
77 \\
18 \\
1 \\
3\end{array}$ & $\begin{array}{c}50 \\
38 \\
9 \\
1 \\
2\end{array}$ \\
\hline $\begin{array}{l}\text { Period of time since } \\
\text { respondents began using } \\
\text { the Internet }\end{array}$ & $\begin{array}{l}\text { One year } \\
\text { Two years } \\
\text { Three years } \\
\text { Four years }\end{array}$ & $\begin{array}{l}204 \\
204 \\
204 \\
204\end{array}$ & $\begin{array}{c}13 \\
18 \\
23 \\
150\end{array}$ & $\begin{array}{c}6 \\
9 \\
11 \\
74\end{array}$ \\
\hline
\end{tabular}

Source: Author's own construction 
devices for more than 4 years were the smallest number $(27 \% ; n=56)$. The findings of a recent study conducted by Isaacs (2012:1) reveal that due to poverty, millions of schoolgoing teenagers and young adults in developing countries still cannot afford to own new mobile devices. Therefore, the trend observed in the present study could be attributed to the fact that these students are Generation $\mathrm{Y}$ individuals who, four years ago, were under the supreme custody of their parents or guardians and were probably restricted in their financial ability to access newer mobile devices.

Most respondents used either MTN (50\%; $n=104)$ or Vodacom $(37 \% ; n=77)$ as their network providers. The majority of the respondents $(74 \% ; 150)$ had used the Internet for over 4 years, with the fact that the respondents were regular users of the Internet being evidenced through the fact that approximately $75 \%(n=154)$ had used the Internet in the previous 30 days before completing the questionnaire. Notably, $70 \%(n=143)$ of the respondents had used amounts not exceeding R200 on Internet purchases, with $67 \%(n=136)$ of the respondents spending more than five minutes on any single Internetbased transaction they conduct. This finding could point to either the students' limited financial status or the fact that they are not very conversant with high value Internet-based transactions.

\section{Reliabilities}

The Cronbach alpha values for the five subfactors are shown in Table 2.

TABLE 2: Cronbach alpha values.

\begin{tabular}{lccc}
\hline Dimension & $\begin{array}{c}\text { Number of } \\
\text { items }\end{array}$ & $\begin{array}{c}\text { Cronbach's } \\
\text { alpha }\end{array}$ & $\begin{array}{c}\text { Standard } \\
\text { deviation }\end{array}$ \\
\hline Perceived enjoyment & 11 & 0.747 & 0.645 \\
Perceived usefulness & 6 & 0.716 & 0.497 \\
Perceived ease of use & 6 & 0.875 & 0.638 \\
Mobile commerce application & 4 & 0.898 & 0.588 \\
Subjective norms & 10 & 0.714 & 0.560 \\
\hline
\end{tabular}

Source: Author's own construction

Cronbach alpha of the overall scale $=0.863$
Table 2 shows that the reliabilities of the overall mobile commerce acceptance scale as well as the individual subscales, as measured using the Cronbach alpha, ranged between 0.714 and 0.898 . As suggested by Hair et al. (2010:385), alpha values greater than \pm 0.3 may be considered as adequate; whilst alpha values greater than \pm 0.4 may be considered important and those alpha values greater than \pm 0.5 are even more important. Therefore, based on that prescription, the reliability of the measurement scale was regarded as sufficient for the purposes of the present study.

\section{Correlations}

Spearman's rho $(r)$ was used to examine the relationship between the outcome as defined by the five m-commerce acceptance subscales (independent variables) and frequency of use (dependent variable). This correlation test statistic is used to describe the existence as well as the strength and direction of the association, as reported in Table 3.

The results of the correlation tests (Table 3) depicted weak, moderate and strong correlation coefficients ranging between 0.164 and 0.677 at both the $p<0.01$ and $p<0.05$ significance levels (2-tailed test). As stated in Wegner (2008:617), correlation coefficient values ranging between 0 to +0.49 (or -0.49 ) depict little or weak relationships whereas correlation values ranging between $+0.50(-0.50)$ to +0.99 (or -0.99$)$ indicate moderate to strong relationships. These findings are in line with Safeena, Hundewale and Kamani (2011:231), Mohd Suki and Mohd Suki (2011:4) and Koutras (2006:120).

Since the relationships amongst PE, PU, PEOU, MCA, SN and frequency of use showed positive correlations, regression analysis was deemed appropriate for establishing whether or not predictive causality exists between the five predictors or explanatory variables and their relative measurement response. The 'enter' method of regression was used with Durbin-Watson's autocorrelation test statistic as reported in Table 4.

TABLE 3: Mobile-commerce acceptance: Inter-dimensional correlation analysis.

\begin{tabular}{|c|c|c|c|c|c|c|}
\hline Construct and Dimension & MCA & PEOU & $\mathrm{PE}$ & SN & PU & Frequency of use \\
\hline Mobile commerce application & 1 & - & - & - & - & - \\
\hline Perceived ease of use & $0.164 \dagger$ & 1 & - & - & - & - \\
\hline Perceived enjoyment & $0.319 \ddagger$ & $0.286 \$$ & 1 & - & - & - \\
\hline Subjective norms & $0.148 \%$ & $0.184 末$ & $0.233 \ddagger$ & 1 & - & - \\
\hline Perceived usefulness & $0.239 \%$ & $0.276 \%$ & $0.308 \ddagger$ & $0.253 \ddagger$ & 1 & - \\
\hline Frequency of use & $0.285 \%$ & $0.402 \%$ & $0.677 \ddagger$ & $0.348 \%$ & $0.213 \%$ & 1 \\
\hline
\end{tabular}

Source: Author's own construction

Source: Author's own construction
$\dagger$, Correlation is significant at the 0.05 level (2-tailed); $¥$, Correlation is significant at the 0.01 level (2-tailed).

MCA, mobile commerce application; PEOU, perceived ease of use; PE, perceived enjoyment; PU, perceived usefulness; SN, subjective norms.

TABLE 4: Regression analysis: Mobile-commerce acceptance and frequency of use.

\begin{tabular}{lcccc}
\hline $\begin{array}{l}\text { Independent variables: } \\
\text { M-Commerce acceptance constructs }\end{array}$ & & & Dependent variable: Frequency of use \\
\cline { 2 - 4 } & Beta & Sig & Collinearity statistics & Tolerance \\
\hline Mobile commerce application & & & 0.039 & 0.645 \\
Perceived ease of use & 0.111 & 1.615 & 0.000 & 0.494 \\
Perceived enjoyment & 0.024 & 0.355 & 0.003 & 0.451 \\
Subjective norms & 0.080 & 1.100 & 0.183 \\
Perceived usefulness & 0.148 & 2.290 & .018 & 0.563 \\
\hline
\end{tabular}


The regression analysis revealed that the five $\mathrm{m}$-commerce subscales (adjusted $R^{2}=0.674$ ) explain approximately $67 \%$ of the variance on the frequency of m-commerce usage. Furthermore, the five m-commerce acceptance constructs contributed positively toward frequency of m-commerce usage amongst Generation Y consumers; with subjective norms making the highest contribution, followed by PU, MCA, PE and PEOU, respectively.

One of the assumptions that is made about the error term for the linear regression problem is the absence of multicollinearity. Field (2005:349) suggests that if the variance inflation factor (VIF) is greater than 10 it implies that the predictor variables are correlated amongst themselves, hence collinearity is a cause for concern. The VIF for the five subscales in the current study ranged between 1.039 and 1.268, which implies that multicollinearity is not a problem for the current study. The F-statistic obtained was 15.159 significant at $p<0.05$. Furthermore, all five predictors were statistically significant at $p<0.05$; with perceived ease of use revealing the strongest statistically-significant results at $p=0.000$.

\section{Discussion}

The subjective norms dimension $(\beta=0.148 ; t=2.290 ; p=0.108)$ is significantly and positively correlated with frequency of use $(r=0.348 ; p<0.05)$. The findings of the present study suggest that frequency of use of mobile technology amongst Generation Y individuals increases significantly as social pressure and peer influences increase. Consistent with this finding, Shambare et al. (2012:574) conjectured that usage behaviour of mobile phones by young consumers is largely shaped by social influence and peer group opinions. Members of the group may exhibit cohesiveness even against their own feelings and beliefs in order to show how critical they consider being accepted socially (Shi 2004; Taylor \& Todd 1995:172). Therefore, by understanding the sociallyaccepted norms and standards amongst Generation $Y$ groups, marketers may be able to increase the frequency of use of $\mathrm{m}$-commerce technologies by individuals who fall into that age cohort.

Regarding the relationship between perceived usefulness $(\beta=0.143 ; t=2.004 ; p=0.046)$ and frequency of use, a positivelysignificant correlation $(r=0.402 ; p<0.05)$ was found. This finding demonstrates that Generation $\mathrm{Y}$ individuals are likely to use m-commerce technologies when they perceive that the technologies they are using can either enhance the performance of a given task or expedite the execution of transactions. As suggested by Awa et al. (2010:13), most users of emerging mobile technologies expect a positive use-performance relationship when they perceive a high level of usefulness of the specific application. A myriad of mobile devices provide a variety of features that afford the consumer an unequivocal opportunity to enhance the effectiveness of each commercial transaction. These features include, for example, the provision of sufficient marketing and advertising information to consumers (Rehman \& Coughlan 2011:594), affordability, anytime-anywhere access and portability of the device (Safeena et al. 2011:228), personalisation of features (Gao et al. 2010:578) and localisation (Elphick 2007:35).

In the present study, it was also found that mobile commerce application $(\beta=0.111 ; t=1.615 ; p=0.039)$ is statistically significant and correlated positively $(r=0.285 ; p<0.05)$ to frequency of use. This finding depicts that an increase in the number of available $\mathrm{m}$-commerce applications increases the frequency of use of m-commerce technologies amongst Generation Y consumers. Abdelkarim and Nasereddin (2010:53) advocate that consumers engage more frequently with various dissimilar mobile phone applications. For instance, the mobile phone has evolved to become 'a portable entertainment player for younger consumers' (Salo \& Karjaluoto 2007:71); a new marketing tool for retailers and manufacturers (Kaplan 2012:130); a multichannel shopping device (Gao et al. 2010:576); a navigation and social interaction tool (Shambare et al. 2012:576); a new type of ticket and money (Funk 2004:210; Ondrus \& Pigneur 2006:250); and an interesting channel for transmitting word-of-mouth messages (Liu et al. 2012:22). Therefore, by providing more $\mathrm{m}$-commerce technologies that offer a wide spectrum of applications, marketers will be able to increase the extent to which Generation Y individuals and other consumers use these technologies.

Perceived enjoyment ( $\beta=0.080 ; t=1.100 ; p=0.003)$ was found to be statistically significant and correlated positively $(r=0.6 .77 ; p<0.05)$ with frequency of use. This result illustrates that the higher the levels of fun and excitement that are derived by Generation $Y$ consumers from utilising $\mathrm{m}$-commerce technologies, then the higher will be the frequency of use of that mobile platform will be for commercial transactional purposes. Gao et al. (2010:578) further argue that usage of mobile device-related facilities enables individuals to represent the 'self' through personalised features, games and other tension-reducing tools that help to provide comfort and joy during the online transactional experience. This facet has been heightened by the high interactivity features of tablets and smartphones as a platform for conducting commercial transactions (Bruner \& Kumar 2005:554; Elphick 2007:28).

In terms of the relationship between perceived ease of use $(\beta=0.024 ; t=0.355 ; p=0.000)$ and frequency of m-commerce use, the study showed positive and statistically significant results $(r=0.402 ; p<0.05)$. This finding implies that Generation Ys are more inclined to use $\mathrm{m}$-commerce technologies that they perceive to be user friendly. This is congruent with Mohd Suki and Mohd Suki's (2011:6) assertion that consumers who find the usage of technology to be effortless (both mentally and physically) are likely to have a greater propensity to rely heavily on the usage of m-commerce transactions rather than traditional brick-and-mortar purchases. Rehman and Coughlan (2011:595) cite the degree of learnability, memorability, efficiency and contextuality as being some of the other essential elements for usability and ease of use of various m-commerce tools. It appears, then, that it is imperative for marketers to ensure that these attributes are embedded within any m-commerce technologies that are targeted at the Generation Y market. 


\section{Limitations and implications of the study}

Despite the efforts made by researchers to reduce any methodological inconsistencies pertaining to the study, some grey areas still remain, which should be mentioned. Firstly, the study was conducted at only one institution, which limits generalisability of the findings to other settings and contexts. This creates the need to conduct similar studies using a wider scope, such as through a cross-section of Generation $Y$ students amongst universities in different provinces, or even on a country-wide level. Secondly, the study used a convenience-sampling technique, which is susceptible to sampling bias. Notwithstanding this aspect, the inclusion of both undergraduate and postgraduate students from all faculties in the institution in the eventual sample used in the study had the effect of increasing sample representativeness, thereby reducing sampling bias.

The present study is not without implications for further research. The results of the present study present sufficient grounds to examine Generation $Y$ technology-acceptance issues along with the dimensions that were excluded from the present study, such as gender and geographic region, and amongst other Generation Ys who have been excluded from most studies (for example, those who are neither employed nor enrolled at higher-education institutions). Similar studies could also be extended to age cohorts other than Generation Ys.

For m-commerce researchers, the study provides empirical evidence for the fundamental interconnection that exists between m-commerce acceptance and frequency of use of m-commerce technologies, as well as the m-commerceorientated behaviour of Generation $\mathrm{Y}$ consumers. For marketers, frequency of usage can assist in determining the potential of m-commerce toward building sustainable businesses and long-term profitability. By intensifying the five $\mathrm{m}$-commerce acceptance dimensions that were identified in this study and aligning each one to frequency of use, it is possible to enhance the latter, thereby increasing the potential for increased competitive advantage and profitability for marketing organisations.

\section{Conclusion}

The study demonstrates that there is a positive association between m-commerce acceptance and the frequency of use of $\mathrm{m}$-commerce technologies. Frequency of use of $\mathrm{m}$-commerce technologies amongst Generation $\mathrm{Y}$ individuals and groups increases when each of the five m-commerce acceptance dimensions, namely, (1) m-commerce applications, (2) subjective norms, (3) perceived ease of use, (4) perceived usefulness and (5) perceived enjoyment increases. Ultimately, sustaining the interest and engagement of Generation $Y$ consumers in using m-commerce technologies could be either enhanced or reduced depending on the intensities of each of these five dimensions. It is therefore of utmost importance that m-commerce acceptance attributes be optimised with a view to enhancing continuation and increased frequency of m-commerce technology usage.

\section{Acknowledgments}

We are indebted to our youthful respondents (the Generation $Y$ consumers) for their important contribution to this work. Grateful acknowledgement is further extended to the Vaal University of Technology for financial support and assistance towards getting this paper published.

\section{Competing interests}

The authors declare that they have no financial or personal relationship(s) which may have inappropriately influenced them in writing this article.

\section{Authors' contributions}

N.D. (Department of Marketing, Vaal University of Technology) was the project leader and she was responsible for the conception and design of the study as well as the manuscript writing process. C.M. (Department of Logistics, Vaal University of Technology) performed the data collection and assembly. N.D. and C.M. were both involved in the data analysis and interpretation procedures. C.M. made language revisions to the final paper.

\section{References}

Abdelkarim, A.A. \& Nasereddin, H.H.O., 2010, 'Mobile commerce', Journal of Mathematics and Technology 1(4), 51-56.

Agarwal, R. \& Karahanna, E, 2000 'Time flies when you're having fun: cognitive absorption and beliefs about information technology usage', Management Information Systems Quarterly 24(4), 665-694. http://dx.doi.org/10.2307/3250951

Ajzen, I., 1985, 'From intentions to actions: a theory of planned behavior', in J. Kuhl \& J. Beckmann (eds.), Action control: from cognition to behavior, pp. 11-39, Springer Verlag, New York.

AlHinai, Y.S., Kurnia, S. \& Johnston, R.B., 2007, 'Adoption of mobile commerce services by individuals: a meta-analysis of the literature', Proceedings of the sixth International Conference on the Management of Mobile Business, ICMB, viewed 12 April 2013, from http://ec.iem.cyut.edu.tw/drupal/sites/default/files/THE\%20 PAPER_Final.pdf

Awa, H.O., Nwibere, B.M. \& Inyang, B.J., 2010, 'The uptake of electronic commerce by SMEs: a meta theoretical framework expanding the determining constructs of TAM and TOE frameworks', Journal of Global Business and Technology 6(1), 1-27.

Bruner, G.C. \& Kumar, A., 2005, 'Explaining consumer acceptance of handheld internet devices', Journal of Business Research 58(5), 553-558. http://dx.doi.org/10.1016/j. jbusres.2003.08.002

Burns, E., 2005, 'Teen, college students are most active cell phone users', viewed 18 November 2012, from http://www.clickz.com/3530886

Cant, M.C. \& Machado, R., 2005, Marketing success stories, 5th edn., Oxford University Press, Cape Town.

Cheung, C., Zhu, L., Kwong, T., Chan, G. \& Limayem, M., 2003, 'Online consumer behaviour: a review and agenda for future research', in Proceedings of the 16th Bled eCommerce Conference, pp. 194-218, viewed 12 April 2013, from https:// domino.fov.uni-mb.si/proceedings.nsf/16Cheung.pdf

Clarke, C., 2000, 'Coming attraction', Wireless Review 17(12), 12-16.

Davis, F.D., 1989, 'Perceived usefulness, perceived ease of use and user acceptance of information technology', MIS Quarterly 13(3), 319-340. http://dx.doi.org/ $10.2307 / 249008$

Davis, F.D., Bagozzi, R.P. \& Warshaw, P.R..., 1989, 'User acceptance of computer technology: a comparison of two theoretical models', Management Science 35(8), 982-1002. http://dx.doi.org/10.1287/mnsc.35.8.982

Donner, J., 2008, 'Research Approaches to Mobile Use in the Developing World: A Review of the Literature', The Information Society 24(3), 140-159. http://dx.doi. org/10.1080/01972240802019970

Du Plessis, L., Berndt, A. \& Petzer, D., 2009, 'The attitude of Generation Y students at a South African university towards' supporting charitable organisations', Global Business and Technology Association Journal 12(1), 1-11. 
Elphick, K., 2007, 'The role of mobile phone web utilisation in creating economic growth in South Africa', MBA dissertation, Gordon Institute of Business Science, Growth in South Africa', University of Pretoria, Pretoria.
Und

Fassnacht, M. \& Koese, I., 2006, 'Quality of electronic services: Conceptualizing and testing a hierarchical model', Journal of Service Research 9(1), 19-37. http://dx.doi. org $/ 10.1177 / 1094670506289531$

Field, A., 2005, Discovering statistics using SPSS, 2nd edn., Sage Publishers, London.

Fishbein, M. \& Ajzen, I., 1975, Belief, attitude, intention and behaviour: an introduction to theory and research, Addison-Wesley, Reading, MA.

Flavián, C., Guinalíu, M. \& Gurrea, R., 2006, 'The role played by perceived usability, satisfaction and consumer trust on website loyalty', Information \& Management satisfaction and consumer trust on website loyalty', Inform
43(1), 1-14. http://dx.doi.org/10.1016/j.im.2005.01.002

Funk, JL., 2004, 'Key technological trajectories and the expansion of mobile Internet applications', The Journal of Policy Regulation and Strategy for Telecommunications 6(3), 208-215. http://dx.doi.org/10.1108/14636690410549543

Gao, T.T., Sultan, F. \& Rohm, A.J., 2010, 'Factors influencing Chinese youth consumers' acceptance of mobile marketing', Journal of Consumer Marketing 27(7), 574-583. http://dx.doi.org/10.1108/07363761011086326

Hair, J.F., Black, B., Babin, B., Anderson, R.E., Tatham, R.L. \& Black, W.C., 2010, Multivariate data analysis: a global perspective, Pearson Education, New York.

Hodge, J., 2005, 'Tariff structures and access substitution of mobile cellular for fixed line in South Africa', Telecommunications Policy 29(7), 493-505. http://dx.doi. org/10.1016/j.telpol.2005.05.001

Hsu, C.L. \& Lu, H.P., 2004, 'Why do people play on-line games? An extended TAM with social influences and flow experience', Journal of Information \& Management 41(7), 853-868. http://dx.doi.org/10.1016/j.im.2003.08.014

International Education Association of South Africa, 2010, 'South African higher education: Facts and figures', viewed 12 November 2012, from http://www.ieasa. studysa.org/resources/Study_SA/Facts_Figures_section.pdf

International Telecommunications Union, 2011, 'ITU Measuring the Information Society ITU ICT Development Index (IDI) 2010 Top five per region', viewed 26 March 2013, from http://www.itu.int/ict/statistics/report/pdf

Isaacs, S., 2012, 'Turning on mobile learning in Africa and the Middle East: Illustrative initiatives and policy implications', UNESCO Working Paper Series on Mobile Learning, United Nations Educational, Scientific and Cultural Organization: de Fontenot, viewed 12 November 2012, from http://unesdoc.unesco.org/images/0021/002163/ 216359e.pdf

James, J. \& Versteeg, M., 2007, 'Mobile phones in Africa: how much do we really know?', Social Indices Research 84(1), 117-126. http://dx.doi.org/10.1007/s11205-0069079-x, PMid:20076776, PMCid:2806217

Kaplan, A.M., 2012, 'If you love something, let it go mobile: Mobile marketing and mobile social media 4x4', Business Horizons 55(2), 129-139. http://dx.doi.org/10.1016/j. social media $4 \times 4$ ', Busin
bushor.2011.10.009

Kim, J., Ma, Y.J. \& Park, J., 2009, 'Are US consumers ready to adopt mobile technology for fashion goods?', Journal of Fashion Marketing and Management 13(2), 215230. http://dx.doi.org/10.1108/13612020910957725

Kothari, C.R., 2008, Research Methodology: Methods and Techniques, 2nd edn., New Age International, New Delhi.

Koutras, E., 2006, 'The use of mobile phones by generation y students at two universities in the city of Johannesburg', MBA dissertation, Department of Business Management, UNISA, Pretoria.

Liu, C.L.E., Sinkovics, R.R., Pezderka, N. \& Haghirian, P., 2012, 'Determinants of consumer perceptions toward mobile advertising - a comparison between Japan and Austria', Journal of Interactive Marketing 26(1), 21-32. http://dx.doi.org/10.1016/j. intmar.2011.07.002

Mathieson, K., 1991, 'Predicting user intentions: comparing the technology acceptance model with the theory of planned behaviour', Information Systems Research 2(1), model with the theory of planned behaviour', Inforn
173-191. http://dx.doi.org/10.1287/isre.2.3.173

Modimogale, L. \& Kroeze, J.H., 2011, 'The role of ICT within Small and Medium Enterprises in Gauteng', Communications of the IBIMA Journal 2011(1), 1-13. http:// dx.doi.org/10.5171/2011.369288

Mohd Suki, N. \& Mohd Suki, N., 2011, 'Exploring the relationship between perceived usefulness, perceived ease of use, perceived enjoyment, attitude and subscribers' intention towards $3 \mathrm{G}$ mobile services', Journal of Information Technology Management 22(1), 1-7.

Mthethwa, Z.D., 2004, 'M-COMMERCE: Standard Bank's cellphone banking adoption by customers', MBA dissertation, Graduate School of Business, University of KwaZulu Natal, Durban, South Africa.
Mutula, S., 2002, 'Current developments in the Internet industry in Botswana', Electronic Library Journal 20(6), 504-511. http://dx.doi.org/10.1108/02640470210454056

Mutula, S. \& Van Brakel, P., 2006, 'E-readiness of SMEs in the ICT Sector in Botswana with respect to information access', The Electronic Library 24(3), 402-417. http:// dx.doi.org/10.1108/02640470610671240

Ngai, E.W.T. \& Gunasekaran, A., 2007, 'A review for mobile commerce research and applications', Decision Support Systems 43(1), 3-15. http://dx.doi.org/10.1016/j. dss.2005.05.003

Ondrus, J. \& Pigneur, Y., 2006, 'Towards a holistic analysis of mobile payments: a multiple perspectives approach', Electronic Commerce Research and Applications 5(3), 246-257. http://dx.doi.org/10.1016/j.elerap.2005.09.003

Osava, M., 2010, 'Rights: Women more educated, not more equal', Inter Press Service/ TerraViva (Rio de Janeiro), Monday, March 01, viewed 12 November 2012, from http://www.globalissues.org/news/2010/03/01/4685

Pearson, M.J. \& Grandon, E.E., 2004, 'Electronic commerce adoption: an empirical study of small and medium sized US businesses', Journal of Information and Management 42(1), 197-216. http://dx.doi.org/10.1016/j.im.2003.12.010

Phillips, P., 2003, E-business strategy, McGraw Hill Publishers, Maidenhead, Berkshire.

Rehman, S.U. \& Coughlan, J.L., 2011, 'Building trust of mobile users and their adoption of M-Commerce', World Academy of Science, Engineering and Technology 75(1) 593-597.

Safeena, R., Hundewale, N. \& Kamani, A., 2011, 'Customer's adoption of mobile commerce: a study of an emerging economy', International Journal on e-Education, e-Business, e-Management and e-Learning 1(3), 228-233.

Salo, J. \& Karjaluoto, H., 2007, 'Mobile games as an advertising medium: Towards a new research agenda', Innovative Marketing 3(1), 71-84.

Santos, J., 2003, 'E-Service quality: a model of virtual service quality dimensions', Managing Service Quality, 13(3) 233-246. http://dx.doi.org/10.1108/09604520310476490

Schiffman, L.G. \& Kanuk, L.L., 2010, Consumer Behaviour, 10th edn., Prentice Hall, Upper Saddle River, N.J.

Shambare, R., Rugimbana, R. \& Zhowa, T., 2012, 're mobile phones the 21st century addiction?', African Journal of Business Management 6(2), 573-577.

Shi, H.P., 2004, 'An empirical study on predicting user acceptance of e-shopping on the web', Information \& Management 41(3), 351-368. http://dx.doi.org/10.1016/ S0378-7206(03)00079-X

Sudman, S. \& Blair, E., 1998, Marketing research: A problem solving approach, McGrawHill, Boston.

Statistical Package for the Social Sciences (SPSS), 2012, SPSS Version 20, viewed 01 October 2012, from http://cibm.com/software/analytics/spss

Taylor, S. \& Todd, P.A., 1995, 'Understanding information technology usage: a test of competing models', Information Systems Research 6(2), 144-176. http://dx.doi. org/10.1287/isre.6.2.144

Thottam, J., 2005, 'How kids set the (ring) tone', The Times, April 4, pp. 30-31.

Ulhøi, J. \& Jørgensen, F., 2008, 'M-commerce exploitation: a SME business model perspective', paper presented at the Proceedings of the 7th Global Mobility Roundtable, Auckland, viewed 15 December 2012, from http://www.worldcat. org/title/innovative-services-through-mobile-technologies-7th-global-mobilityroundtable-conference-23-25-november-2008/oclc/298324862

Uzoka, F.M.E., Shemi, A.P. \& Seleka, G.G., 2007, 'Behavioural influences on E-Commerce adoption in a developing country context', Electronic Journal of Information Systems in Developing Countries 31(4), 1-15.

Van Rooi, L., 2011, 'Generation Y and the concept of family. An introductory study of the unique characteristics of Generation $Y$ with specific reference to the concept
of family within the context of the URCSA', Nederduitse Gereformeerde Teologiese of family within the context of the URCSA', Nederduitse Gereformeerde Teologiese
Tydskrif (NGTT), 52 (Supplement), 43-51. http://dx.doi.org/10.5952/52-0-35

Venkatesh, V., 2000, 'Determinants of perceived ease of use: integrating control, intrinsic motivation and emotion into the Technology Acceptance Model', Information
Systems Research 11(4), 342-365. http://dx.doi.org/10.1287/isre.11.4.342.11872

Venkatesh, V., Speier, C. \& Morris, M.G., 2002, 'User Acceptance enablers in individual decision making about technology: toward an integrated model', Decision Sciences 33(2), 297-315. http://dx.doi.org/10.1111/j.1540-5915.2002.tb01646.x

Wegner, T., 2008, Quantitative methods for marketing decisions, Juta Academic Publishers, Cape Town.

Wu, J.H. \& Wang, S.C., 2005, 'What drives mobile commerce? An empirical evaluation of the revised technology acceptance model', Journal of Information and Management 42(5), 719-729. http://dx.doi.org/10.1016/j.im.2004.07.001 